Article

\title{
National Land Use Policy against the Misuse of the Agricultural Land-Causes and Effects. Evidence from Poland
}

\author{
Alina Źróbek-Różańska *—i] and Joanna Zielińska-Szczepkowska \\ Department of Economic and Regional Policy, University of Warmia and Mazury, Michała Oczapowskiego 2, \\ 10719 Olsztyn, Poland; joanna.zielinska@uwm.edu.pl \\ * Correspondence: alina.zrobek@uwm.edu.pl
}

Received: 11 October 2019; Accepted: 12 November 2019; Published: 14 November 2019

\begin{abstract}
Land suitable for agricultural production is limited and should be used in a sustainable manner and protected. Countries of the former communist bloc, where the majority of the agricultural land was dynamically privatized, are in a special situation. Land has been used there also to serve the needs of growing cities, for investment speculation and as entitlement to subsidies. Therefore, legal regulations protecting agricultural land were introduced. In the case of Poland, particular attention should be paid to the radical act of 2016, which completely stopped the sale of Treasury resources and strongly limited sales on the private market. However, the new act caused a number of side effects and various pathologies. This article examines the real effects of policy aimed at combating the misuse of agricultural land. It was assumed that most of the side effects will be observed around big cities, defined as Functional Urban Areas. The following methods were used: a survey in Polish FUAs, analysis of transactions on the real estate market in 2015-2018 and in-depth interviews with representatives of local governments and relevant institutions. The study revealed a number of pathologies, such as ways of circumventing new restrictions or searching for legal loopholes.
\end{abstract}

Keywords: sustainable land use; land use policy; agricultural land; spatial economics; land use planning

\section{Introduction}

For centuries, agricultural land has been the basis of human existence, the most important means of food production and the source of nutrition for the whole society. In 2018, the land where agricultural crops were grown covered 38\% of the world's land area [1] and 35\% of land in Europe, providing food, energy, and fibre. Moreover, it is also the basis for shaping cultural differences, the ecosystem balance and spatial order. As an object of ownership, it is treated by the owners as the heritage of many generations, which determines their social and property-related status in local communities. The development of civilization and urbanization and infrastructure processes, as well as the lack of a coherent concept for shaping relations between urban and rural areas, leads to a growing imbalance in their development. Urban areas develop at the expense of rural areas, and metropolization and the accompanying suburbanization and counter-urbanization processes take place without any role for rural areas, which are usually treated as the surroundings of the settlement system, rather than its integral part. They are only a background, or even a barrier, and most often provide a base and reservoir of land necessary for urbanization processes. Climate change also has a negative impact, causing the resources of agricultural land to decrease systematically, either due to changing land use, degradation of production capabilities, or total devastation of the environment [2]. 
Due to geographical, physical, and climatic conditions, as well as changes in management, land resources suitable for agricultural production are scarce and limited. They should therefore be used in a sustainable manner and particularly protected from inappropriate, degrading methods of use. The scarcity of agricultural land resources can be considered both globally and locally [3]. According to some scientists, global resources of land used for agricultural purposes are shrinking as a result of the progressive climate change and gradual draining of areas [4] and intensive urbanization [5]. The pressure of cities on the surrounding areas is observed worldwide: in the United States, Poland [6], China [7], and Nepal [8]. At the same time, the growth of the global population, as well as the changing model of consumption, puts pressure on an increase in agricultural production through the expansion of agriculture, which results in the use of areas previously occupied by natural ecosystems for agricultural purposes $[9,10]$. The acquisition of new areas of agricultural land causes consequences of an ecological nature, e.g., growing deforestation [11,12], or economic consequences, e.g., impoverishment of local populations. Free trade in land on the international market also leads to what is called land displacement. This term denotes the use of land located in one country to satisfy the consumption needs of inhabitants of another country. This phenomenon has become a global phenomenon with the growth of international food markets, the development of global trade, and decreasing transport costs. Large-scale purchases of land by international companies do not always serve the needs of the population of the country where the land is located, as food is exported and the local availability of food products deteriorates as a result [13]. One of the serious problems associated with the management of agricultural real estate in the EU is the cross-border process of taking actual control of large areas of agricultural land (land grabbing). Globalization processes have significant social and economic consequences, including restrictions on local producers' agricultural activity, land use changes, decreasing food security and sovereignty in the countries where investments are made, and degradation of the natural environment [14-16]. At the same time, it is noteworthy that the land is not used evenly, as the world is witnessing both deforestation for crops [17] and land abandonment [18]. The need for efficient and sustainable use of agricultural land resources seems all the more urgent given the future diminishing of these resources as a result of progressing climate change $[19,20]$. This means conducting a cautious policy of using natural resources following the concept of sustainable development, i.e., "Development which meets the needs of the present, without compromising the ability of future generations to meet their own needs" [21]. Sustainable development integrates three dimensions of human-natural systems—social, environmental, and economic dimensions [22]. Therefore, one can say that it requires frugal management of land suitable for agricultural production and prevention of its misuse. In practice, this requires an introduction of a number of regulations protecting both agricultural land and the environment, as well as different parts of the global population.

The countries of the former communist bloc, where a significant portion of the agricultural land was nationalized after World War II and then privatized as a result of the political transformation and transition to a market economy, are in a special situation. At the end of the 20th century, agricultural land in these countries was the subject of intensive trading on an immature real estate market, with constantly changing regulations affecting the conditions for land purchase and sale transactions. The natural consequence of the transformation was to free the market, mainly for economic reasons [23]. As a result of the privatization of agricultural land, land changed its owners, users, and the way land was used also changed. In practice, new land use did not always mean continuing agricultural production. Agricultural land started to serve the needs of growing cities, a means of capital investment, an object of investment speculation, and, following Poland's accession to the European Union, it was also acquired for the sole purpose of seeking entitlement to subsidies. Therefore, when groups representing the interests of farmers and villagers came to power, various legal regulations protecting the status of agricultural land were introduced. These perceived dangers led to legislative changes in some EU countries, involving the introduction of rigorous solutions concerning the trade in agricultural real estate and the search for adequate solutions in the regulations of European law. Changes in the legal system governing the trade in agricultural real estate took place, among others, in Slovakia [24], 
Hungary [25], Poland [26], Latvia [27], Lithuania [28], Bulgaria [29], and Romania [30]. As a consequence of undertaking new extended protective regulations in the field of trade in agricultural real estate, the European Commission undertook to develop issues concerning the importance of land resources for the European model of agriculture, as well as to check the compliance of national regulations with the EU law. The provisions of the Treaty do not call into question the power of the Member States to establish their own legal regulations concerning the acquisition of agricultural land, especially when such a regime is justified by objective reasons: the general interest and the principle of proportionality [31]. In the case of Poland, particular attention should be paid to the radical act of 2016, which completely stopped the sale of Treasury resources and strongly limited sales on the private market. However, radical legal solutions usually stimulate informal solutions. For example, in India, when land tenancy was prohibited by law in order to protect exploited tenants, a significant number of farms without land became dependent on informal tenancy [32]. This also happened in Poland; apart from the intended effect of protection of agricultural land against improper use, the new act caused a number of side effects and contributed to the emergence of various pathologies among the entities operating on the Polish real estate market.

The article has theoretical and empirical character. Selected items of literature and relevant legal acts were reviewed (e.g., the Act of 14 April 2016 on suspending the sale of agricultural property of the State Treasury and amending certain acts [Journal of Laws 2016, item 585] and methods of state intervention in the trade in agricultural real estate in EU states). In the empirical part of the article, the real (intended and side) effects of the introduction of policies aimed at combating the misuse of agricultural land are examined. It was assumed that most of the side effects will be observed in rural areas located around big cities (these areas are subject to the strongest urbanization pressure), defined in Poland as Functional Urban Areas (FUAs). The following methods were used in the survey: a survey was conducted among the communes in all FUAs in Poland, transactions concluded on the real estate market in the years 2015-2018 in a selected FUA were analysed and in-depth interviews were conducted with representatives of local governments, employees of commune offices and employees of the Agricultural Property Agency (currently National Support Centre for Agriculture - NSCA). The study revealed a number of new pathologies, such as ways of circumventing new restrictions or searching for legal loopholes. The owners of agricultural properties, especially those located in typically agricultural areas, have been affected by the introduction of the new regulations. As a result, in April 2019, changes were introduced to alleviate the restrictions on agricultural real estate trade. The results achieved can be used to forecast the impact of rigorous solutions on land use in other countries as well. It can be assumed that the situation described for Poland as an example may also occur in another country if strong restrictions on the freedom of transactions are introduced in that country. Therefore, the situations presented may be used to make the expected effects of similar laws more realistic.

\section{Materials and Methods}

\subsection{Agricultural Land in Poland-Historical Approach}

Poland regained independence after World War II and since then (1945) it has existed in an area delimited by the current administrative borders. The current situation on the agricultural land market is a result of many events from the past. The first of them was the agricultural reform, carried out pursuant to the Decree of the Polish Committee for National Liberation of 6 September 1944 [33]. Initially, it involved the distribution of land in the areas liberated from the Nazi occupation, and later also in the so-called Recovered Territories. According to this decree, German citizens and Polish citizens of German nationality, persons convicted of treason against the state and aid to the occupiers (and other offences) and persons having more than 100 ha of total area or 50 ha of agricultural land would be subject to expropriation. These lands, in their entirety and without compensation, became the property of the State Treasury for the purpose of granting them to existing farms under 5 ha, the creation 
of new independent farms and the creation of allotment gardens and agricultural schools. It was stipulated that the farms established under the decree could not be divided, sold, leased, or pledged. In the post-war period (until 1991), agricultural farming in the People's Republic of Poland could take one of the three forms [34]: as an individual farm (from $89.6 \%$ in 1950 to $83.4 \%$ in 1970, with a minimum share of $77.3 \%$ in 1956), a production cooperative (from $0.8 \%$ in 1950 to $1.3 \%$ in 1970 , with a maximum share of $9.2 \%$ in 1956) or a state farm (from $9.6 \%$ in 1950 to $14.8 \%$ in 1970). State-owned farms most often took the form of State Agricultural Farms, which were gradually transformed into agricultural conglomerates. Large conglomerates were created throughout the soviet republics and satellite countries of the communist bloc (GDR, Poland, Czechoslovakia, Bulgaria, Romania, Hungary), although at a different pace. In 1978, the largest progress was observed in Bulgaria, with the GDR at the other end of the spectrum [35].

The beginning of the political transformation (1989) triggered the process of privatization in Poland, and the 21st century brought intensive preparations for accession to the European Union. The restructured farms could be privatized in various ways, with sales being the preferred direction of permanent distribution. By the end of 2016, $70.81 \%$ of the area of land taken over by the agricultural property resources was permanently disposed of [36]. Freedom of economic activity, including the acquisition of agricultural land, is one of the basic principles of the European Community. However, for the countries that accessed the EU in 2004, 2007 and 2013, the difficult post-communist history led to turbulent negotiations on land acquisition. The effect was the so-called transition periods ( 7 years in the Czech Republic, Estonia, Hungary, Latvia, Lithuania, Slovakia, and 12 years in Poland). The end of these periods turned out to be a difficult moment. The governments of Hungary, Slovakia, Lithuania, and Bulgaria decided to continue the protection [37]. The agricultural land market is also protected in Poland, as the legal regulations concerning the acquisition of agricultural real estate (also by foreigners) are among the most rigorous in the world. [38]. The Act on the agricultural system was passed almost on the eve of accession to the EU, in 2003. The Act was expected to decrease the amount of agricultural real estate acquired by unauthorized persons who purchase it for purposes other than agricultural production. However, it was soon noted that it was not effective in protecting the agricultural land market. The fear of the changes taking place as a consequence of the end of the transition period was conducive to the adoption of a new act on 14 April 2016 on the suspension of the sale of real estate from the State Treasury Agricultural Property Stock and on the amendment of certain acts. This Act amended the Act of 23 April 1964, the Civil Code, the Act of 6 July 1982 on Land Registers and Mortgages, the Act of 17 May 1989, the surveying and cartographic law, the Act of 19 October 1991 on the Management of Agricultural Property of the Treasury, the Act of 11 April 2003 on the Agricultural System, and the Act of 8 July 2005 on the Exercise of the Right to Compensation for Abandoning Real Property Outside the Current Borders of the Republic of Poland [39-44]. After three years of operation, the new law was amended. These amendments are contained in the Act of 26 April 2019 amending the Act on the agricultural system and certain other acts [45].

\subsection{Study Area and Methodology}

Due to the intensity of transactions concerning the ownership of agricultural real estate (which is mainly related to migration processes), the research covered communes located within the boundaries of the Functional Urban Areas of cities in Poland. A questionnaire survey was conducted in these communes, excluding the units surrounding the so-called Big Five Cities (Warsaw, Kraków, Łódź, Wrocław, Poznań), as the processes occurring there are unusual and observations are characterized by abnormal levels. The questionnaire form was sent to 96 communes and responses were received by $44 \%$ of them. Respondents were asked about spatial planning, observed change in the number of transactions concluded on the agricultural land market and the real effects of the new regulations on 14 April 2016 that were noticed within the commune's area. The sample was statistically relevant for the finite population with assumed fraction size $50 \%$, level of significance 0,05 and permissible error $10 \%$. 
Detailed studies were performed in six communes which make up the Olsztyn Functional Urban Area (Barczewo, Dywity, Gietrzwałd, Jonkowo, Purda, and Stawiguda, Figure 1.), located in the northeastern part of Poland, in typically agricultural voivodship, Warmia and Mazury. This region is also characterized by large areas of agricultural land that is still owned by the State Treasury.

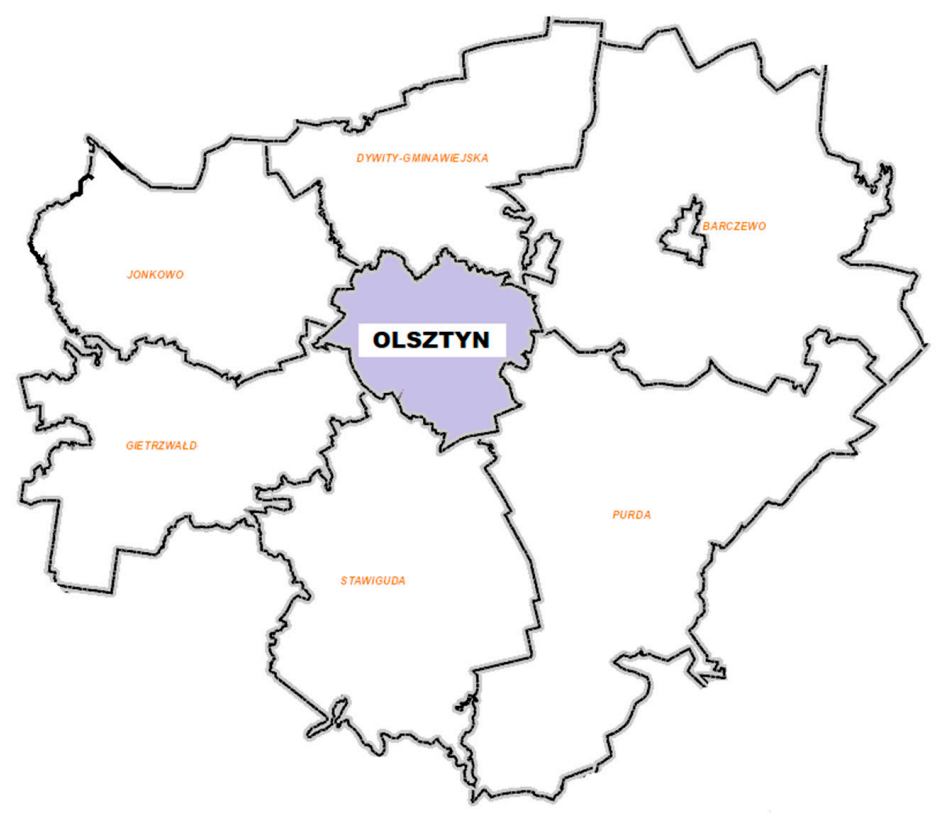

Figure 1. Olsztyn and its Functional Urban Area.

These communes have been subjected to strong suburbanization-since 2009, the centrally located city of Olsztyn has been gradually depopulated, and the populations of these suburban communes have been increasing, with considerable numbers of their members practicing non-agricultural professions (these communes are primarily used as homes for people professionally connected with the city). In the case of the selected communes of FUA Olsztyn, the method of direct interview with representatives of the authorities and heads of spatial management and real estate departments was applied. In addition, data on agricultural real estate transactions concluded in these communes during the period of 2 years-between April 2015 and April 2017-were analyzed (716 transactions). The size, location, and prices of the real estates were compared.

Various data sources were used in the study: quantitative data from the system of public statistics (Local Data Bank of the Poland Statistics); data aggregated by Communal Offices; the transactional price databases for information on prices, location, and size of the real estate; data collected through questionnaire survey. In addition, digital maps and information collected during field inspections were used. Moreover, direct interviews were conducted with representatives of the National Support Centre for Agriculture (NSCA) in Olsztyn and the workers of the Communal Offices (the representatives of local authorities and the departments related to the real estate turnover and management). Being the successor of the Agricultural Property Agency, the NSCA manages the State Treasury agricultural property and ensures law enforcement by monitoring agricultural land turnover. Local authorities are responsible, i.e., for the spatial planning and decision on building and land development conditions. The workers of the departments related to the real estate management also monitor real estate turnover, i.e., by checking the notarial acts and the real land use in the commune. They are also the first contact persons for the potential land buyers or sellers, giving information on the current legal status and gaining the feedback from the interested parties of the potential transaction. Quantitative and qualitative research was preceded by a detailed review of literature and legal acts. It allowed to outline the social and economic situation of Poland in the context of legal regulations influencing the shape 
of the current use of agricultural land resources. The scientific text also presents the ways of state intervention in the trade in agricultural real estate in selected EU states.

\section{Results}

\subsection{Legal Regulations—Reasons for Their Implementation}

Agricultural real estate is an indispensable means of agricultural production, which serves primarily as the food source for the entire society. For these reasons, it is regarded as a public good that cannot be enlarged and, as such, is protected in a special way. One way of protecting it is to introduce suitable legal provisions to ensure that this scarce resource should be distributed properly. On 1 May 2016, 12 years had passed since Poland's accession to the European Union and the protection period for the purchase of agricultural land by foreigners ended. It was expected that Polish agricultural land, deprived of legal protection, would be the object of increased interest from buyers from other EU countries. The prevailing fears were that the Act on the Agricultural System, in force at the time, would not be sufficient to counteract the speculative acquisition of agricultural real estate and that it would not guarantee the use of the purchased land for agricultural purposes. Therefore, the Act of 14 April 2016 was introduced (Journal of Laws of 2016, item 585), pursuant to which the sale of real estate or parts thereof comprising the State Treasury Agricultural Property Stock was suspended for a period of five years. The exceptions to these regulations included real estate and areas designated in the local zoning plan or the land use plan in the commune for non-agricultural purposes, in particular, for technology parks, industrial parks, business and logistics centers, warehouses, transport facilities, house building, and sports and recreation facilities. In addition, the provisions did not apply to real estate for which a decision on land development conditions had been issued (prior to the Act becoming effective); located within the boundaries of special economic zones; houses, apartments, farm buildings and garages with the necessary land and home gardens or agricultural real estate with an area of up to 2 ha. The 2016 Act also amended other Acts. The Act on the agricultural system of 11 April 2003 (Journal of Laws of 2012, item 803), introduced considerable changes in the possibility of purchasing land from private entities. Pursuant to this Act, agricultural land could only be purchased by an individual farmer or their spouse (there were some exceptions). The area of the purchased agricultural real estate together with the area of agricultural real estate included in the buyer's family farm could not exceed 300 ha of agricultural land. An additional restriction contained in this Act was the provision that the purchaser was obliged to run an agricultural farm which included the purchased agricultural real estate for at least 10 years after the date of its acquisition, and if the buyer was an individual, to run it in person. At that time, the real estate could not be sold or transferred to other entities.

The reason for the introduction of this Act was the high probability that after the end of the transitional period there would be an increased interest in the acquisition of agricultural real estate from the Agricultural Property Stock by people who were not farmers. It was also argued that foreigners purchased agricultural land through Polish proxies, which inflated the prices of agricultural land and made it impossible for Polish food producers to buy it. Agricultural land could be purchased for purposes other than agriculture, e.g., as a capital investment in real estate. For an investor, investing capital in a property generates three main sources of income: rental income, non-rental income, and return on capital upon the sale of the property [46]. Rental income in this case is the income received from tenants. Non-rental income includes, for example, the entitlements to receive direct payments [47]. The concept of direct payments appeared as early as the 1960s and 1970s as an alternative to price support and was intended to reduce the impact of interventionism on the increase in prices of agricultural supply products and the reduction of produce surpluses, which increases the costs for both taxpayers and consumers. This mechanism was implemented in the 1980s in countries that played a crucial role in the international agricultural market - the USA and Canada [48]. In the European Union, direct payments became an important instrument for supporting farmers' incomes under the MacSharry reform in 1992, and they were continued under subsequent reforms of the 
Common Agricultural Policy (CAP)—2000 Agenda and the Luxembourg Agreements [49]. Since the beginning of the 1990s, the importance of tariff instruments and institutional prices for direct support instruments has been declining, especially due to direct payments, which are increasingly less linked to current production output [50]. Direct payments are transfers of funds intended to increase farmers' incomes. However, in order for these payments to gain socio-economic legitimacy, they need to be highly effective. However, as critics have pointed out, transfers from taxpayers and consumers to the agricultural sector are of low-income efficiency. In Poland, not more than half of these transfers reach the farmer's households as additional income under all of the agricultural policy instruments applied so far. Up to $46 \%$ of the transfers are capitalized at the price of the land owned by a farmer, and another $45 \%$ provides the income of the owners of the land leased by them. This confirms that direct payments are, in fact, addressed not to agricultural producers but to landowners, irrespective of the legal form of the landholding. On the other hand, the return on capital at the time of sale requires a price increase and is, in fact, a gain for the land seller, who does not have to be a farmer. The introduction of the Act was aimed at ensuring that agricultural land remained in the hands of real farmers, hence the use of instruments to control whether the purchaser actually increased or established an agricultural farm and runs it personally.

\subsection{Legal Regulations-Actual Effects}

In analyzing the actual effects of introducing this rigorous act, it is noteworthy that the same legal act also contains certain exceptions:

- First, the provisions of the acts were applied to agricultural real estate comprising the State Treasury Agricultural Property Stock and to agricultural real estate with an area of more than 0.3 ha.

- Moreover, acquisition by persons other than individual farmers could take place with the consent of the APS, issued at the request of the seller or the potential buyer. The seller had to demonstrate that it was not possible for the persons provided for in the Act to acquire the agricultural real estate, that the buyer gave a guarantee of proper performance of agricultural activity and that the acquisition would not result in excessive concentration of agricultural land.

- If the property had a decision on development and land use conditions for non-agricultural purposes, the Act was also ineffective.

The combination of a rigorous Act and the possibility of exceptions led to changes, both intended and unforeseen (Figure 2.).

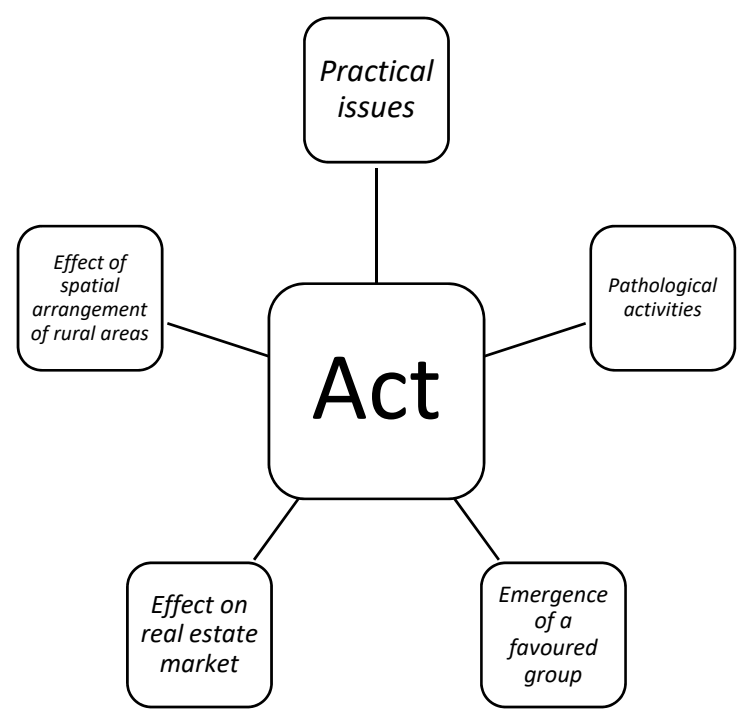

Figure 2. Effects of the act restricting trade in land coming into force. 


\subsubsection{Effect of Spatial Arrangement of Rural Areas}

According to the provisions of the new Act, sales restrictions did not apply to land located in the area covered by the local zoning plan, according to which it is intended for non-agricultural use. However, local planning in Poland requires development—only $31 \%$ of the area was covered by local zoning plans in 2018. The majority (60\%) of the communes in the Polish Functional Urban Areas under study had less than $25 \%$ of the area covered by plans, and only $19 \%$ of them declared that they had a majority of the commune area covered by plans. (Figure 3.).

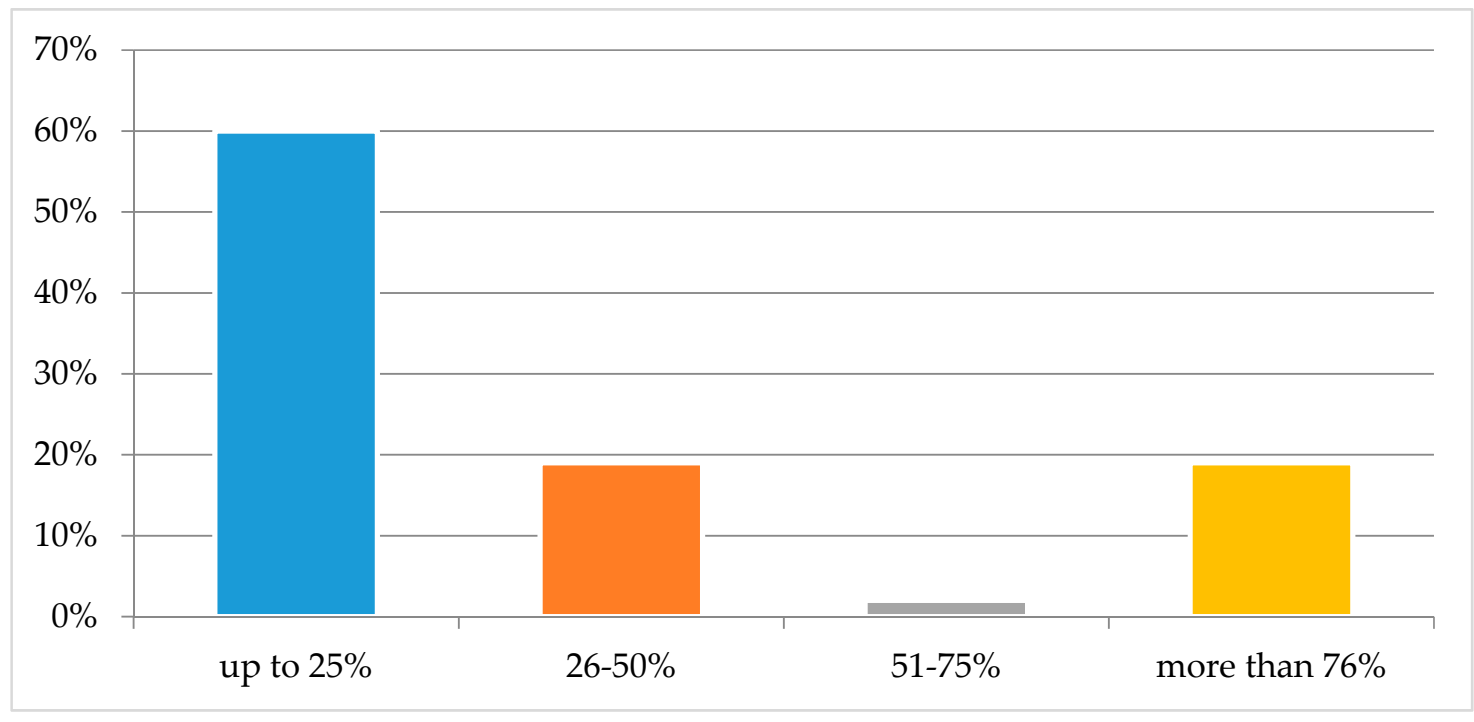

Figure 3. Coverage of the commune area by local plans.

Therefore, it could be suspected that in most suburban communes, the new regulations would significantly limit the trade in real estate in excess of the statutory area of $0.3 \mathrm{ha}$, and the spatial arrangement of the transaction would be shifted to the areas covered by local plans. Confirmation of this regularity was sought among suburban communes of the city of Olsztyn. A comparison of the location of land being the object of transactions concluded within one year prior to and after the introduction of the Act revealed that the share of sold land in the areas covered by local plans increased, on average, from $17 \%$ to $39 \%$. Therefore, introducing order in the spatial structure of rural areas and limiting uncontrolled suburbanization was, to a certain extent, a positive external effect. According to the commune head (representative of local authorities) of one of the suburban communes: "It sometimes happened that someone bought a hectare of land in the middle of fields or forest, and after a long procedure of filing applications and appeals they received permits to build several houses. And then they started a battle for the construction of expensive infrastructure, of course at the expense of the commune. They won't do anything like it now." Therefore, it is noteworthy that the Act also affected the concentration of agricultural land development, which is beneficial from the point of view of spatial order and sustainable development of rural areas.

\subsubsection{Effect on Real Estate Market}

By imposing rigorous restrictions regarding the persons entitled to purchase agricultural land and the area of purchased land, the new act also had an impact on the Polish real estate market. A definite effect was observed in the case of agricultural land owned by the State Treasury (ST). According to the report of the Supreme Chamber of Control, the largest sale of land in the Stock took place in 1996-nearly 193,000 ha, while 17,000 ha were sold in 2016, the sales dropped to 3500 ha in 2017, and to 2500 ha in 2018 [51]. The ST agricultural land price increase was also halted (from PLN 32,255/ha in 2016 to PLN 26,402/ha in 2018). Compared to the previous year, in terms of market and non-market trading in agricultural land, the number of purchase and sale transactions in 2016 decreased by $25 \%$ and 
the number of non-market transactions, especially donations, increased. The decrease in the number of transactions mainly concerned transactions with legal persons, mainly with the APS (a decrease of 75\%) [52].

In the survey, the employees of the real estate departments of commune offices were asked about the change in the number of all transactions on local real estate markets that took place after the introduction of the new law. More than half (54\%) of the surveyed communes had not noted a significant change in the number of transactions; $22 \%$ believed that this number had slightly decreased; and $24 \%$ had noted a significant decrease (Figure 4.). However, it can be expected that in the future a decrease will be more often observed [53].

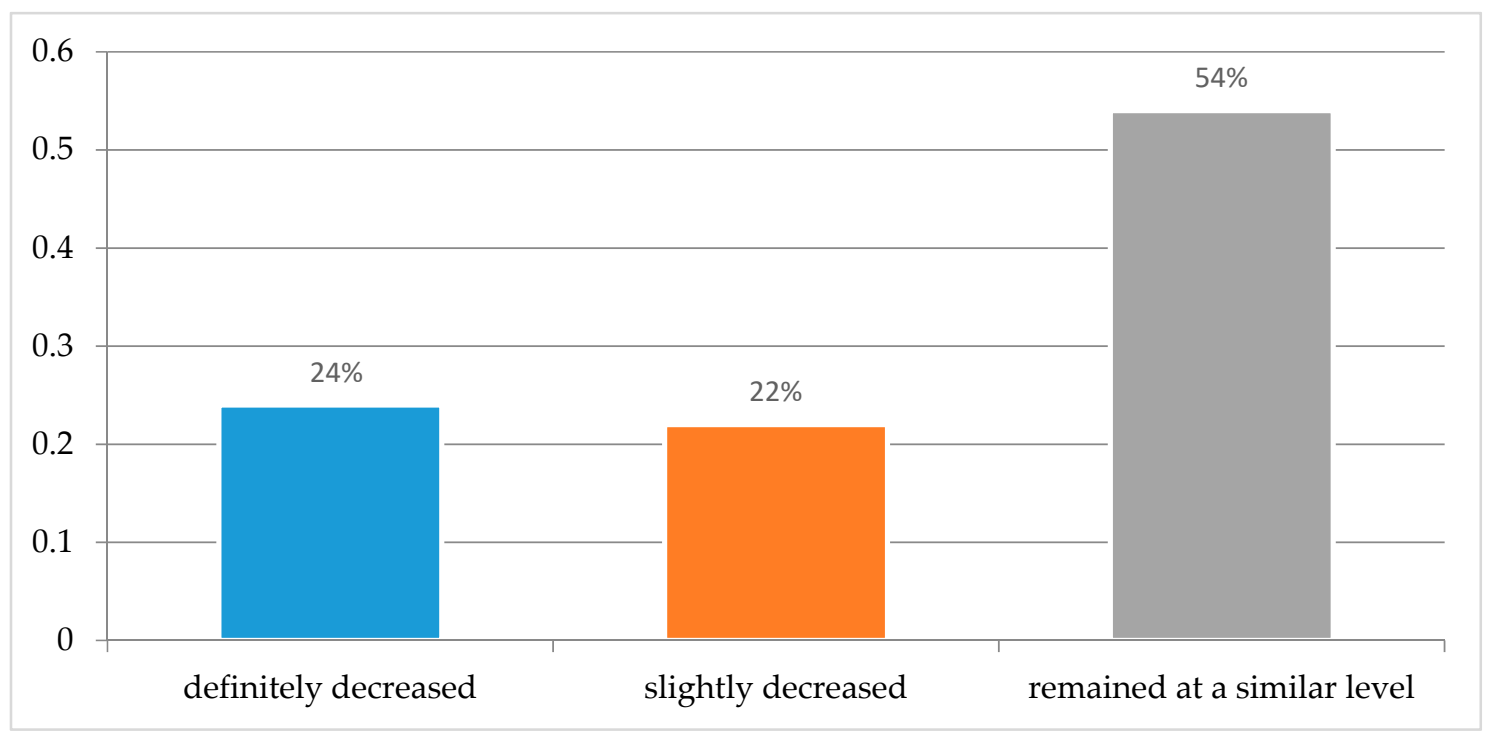

Figure 4. Change of the number of transactions after the Act came into force.

The transactions concluded in the communes of the Olsztyn FUA were analyzed in detail. They were analyzed in terms of the area size and the spatial distribution. The analysis of the transactions led to the following conclusions:

- After the Act came into force, the area-related structure of sold properties in the communes of the Olsztyn FUA under study changed; the share of smaller properties (up to 0.3 ha) increased significantly, from $29 \%$ to $74 \%$, on average;

- The spatial distribution of these transactions also changed. After the new regulations came into force, the share of transactions concluded for real estate located in rural areas located in the close vicinity of Olsztyn or main road leading to the city increased, while it decreased or completely disappeared in typically agricultural areas. This process can be illustrated by the example of the Purda commune. Transactions concluded before the introduction of the new Act were spatially diffused (Figure 5), while after the Act came into force, they became more concentrated (Figure 6). 


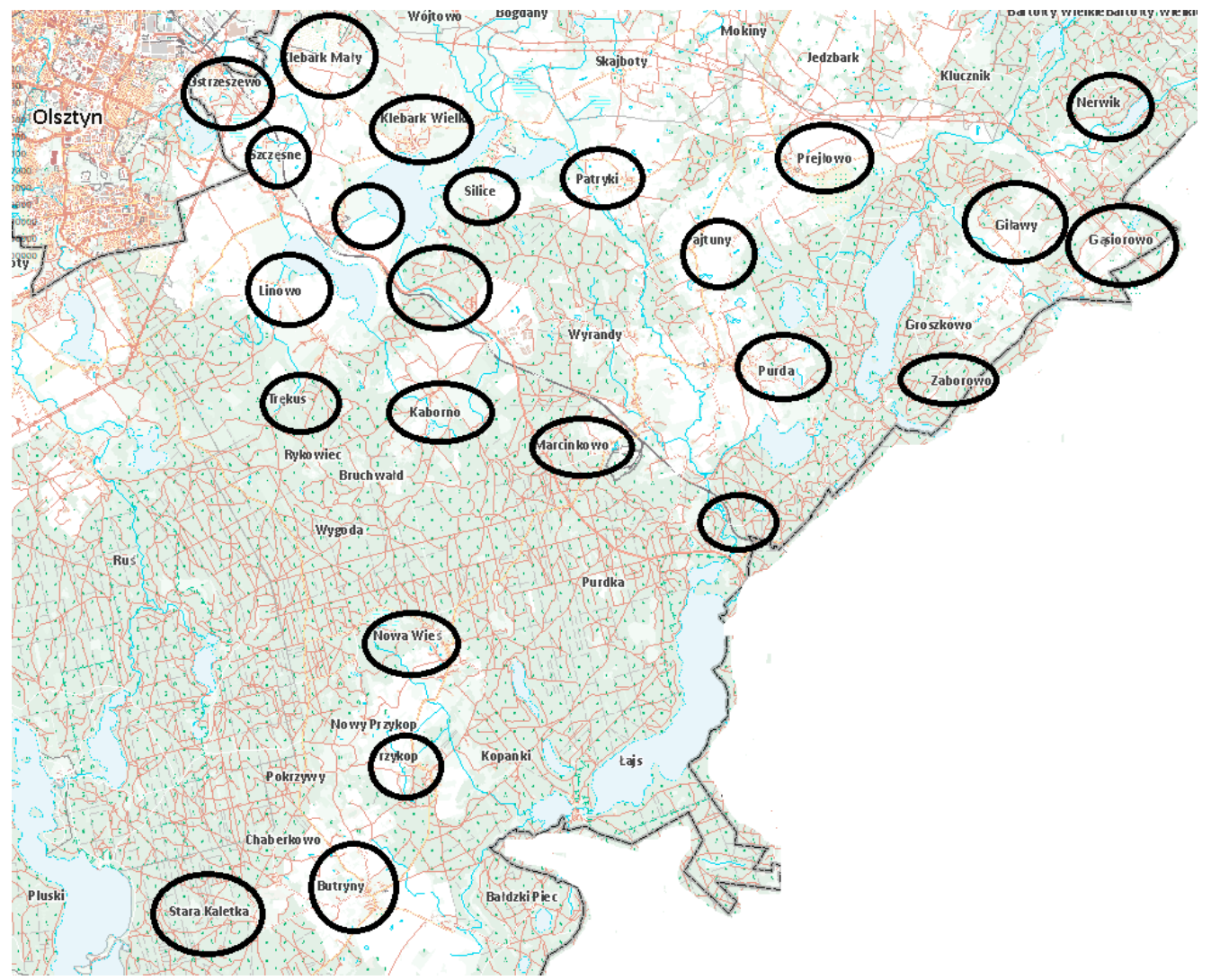

Figure 5. Spatial distribution of transactions concluded in Purda commune before the introduction of the new Act (from April 2015 to April 2016).

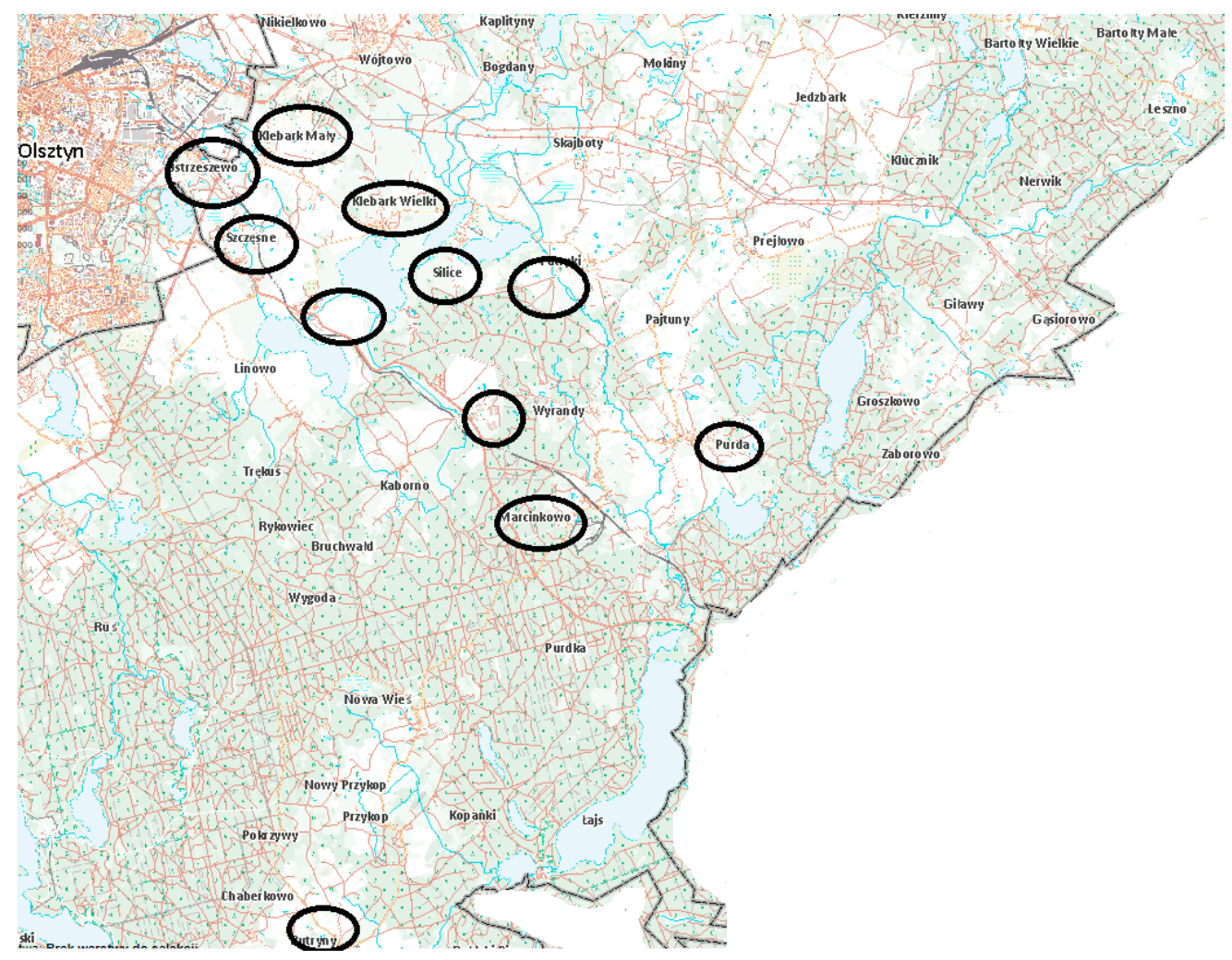

Figure 6. Spatial distribution of transactions concluded in Purda commune after the introduction of the new Act (from May 2016 to April 2017). 


\subsubsection{Emergence of a Favored Group}

Any state intervention in the regulation of property rights infringes the interests of one social group in favor of another. In the policy of shaping the agricultural system in Poland, individual farmers are a group favored in access to land. As a result, the favored group includes persons with agricultural qualifications, living in the area of the commune where the property is located. Persons who did not meet these conditions encountered procedural difficulties or were prevented from acquiring agricultural land. However, it is noteworthy that the privilege lost its actual value when a farmer wanted to sell a property larger than 0.3 ha. The Act strictly restricted the group of potential purchasers, which resulted in many sales transactions being unsuccessful due to the lack of a purchaser meeting the conditions specified in the Act. As was established in the interviews with employees of commune offices who dealt with real estate issues in communes, many owners of agricultural land plots turned to the offices for help on how they could sell their land, because they needed capital, e.g., to invest in their agricultural farm.

\subsubsection{Pathological Activities}

Restrictions imposed by the new law also resulted in people seeking ways to circumvent them. Employees of the offices of the communes under study and the National Support Centre for Agriculture observed the following pathological activities:

- The owners divided agricultural properties in surveying mode into plots of land with an area exceeding 0.3000 ha, and then reduced their area to 0.2998 ha by widening the right-of-way area.

- The sellers reduced plots exceeding 0.3 ha by enlarging the neighboring plot or by regulating the borders, because according to the Act on real estate management "division of a plot located in areas designated in local plans for agricultural and forestry purposes, and-in the absence of a local plan-used for agricultural and forestry purposes, resulting in the segregation of a plot of land with an area of less than 0.3000 ha, is acceptable, provided that this plot is designated for enlargement of the neighboring plot or that the borders between neighboring plots will be regulated".

- Potential sellers applied to the Agency for permission to sell real estate to a person who did not meet the conditions set out in the Act. They argued that the buyers were not interested in the sale despite an announcement being published. In fact, the announcements were: poorly displayed (in rarely visited places), not displayed at all (the seller put it up, took a photo as evidence attached to the application for the Agency and then took it off) or the price in the announcement was significantly inflated to discourage other farmers from purchasing.

- Purchasers who were not farmers submitted applications to the Agency assuring that they would conduct agricultural activity. In fact, the declared agricultural activity meant a backyard garden, and the planned orchard was limited to a few fruit trees.

- A month before the new act came into force, the commune offices were flooded with applications for decisions on land development conditions, which provided for the construction of a house on agricultural plots.

\subsubsection{Practical Issues}

The results of the interviews indicate that farmers do not have full knowledge about the importance of the valid regulations for the agricultural land market in Poland in the context of trade in it, among others: control of private trade in agricultural real estate (apart from the administrative procedure, the right of pre-emption and purchase by the Agricultural Property Agency was left in place), extended right of pre-emption of shares and stocks in companies which own agricultural real estate (except for: sale of shares admitted to trade on the stock exchange and sale of shares and stocks to a close relative), extended applicability of the right of purchase of agricultural real estate from partnerships, as well as in cases where the acquisition results from a decision issued by a court, a public 
administration authority and, in many other cases, with simultaneous determination of exceptions when the right of purchase does not apply). There was a problem with the division of joint property of spouses-due to the rule that the agricultural real estate can only be purchased by an individual farmer, such property can only be owned by the spouse who meets the criteria mentioned in Art. 2a of the Act. The spouse who is not an individual farmer under the law cannot acquire agricultural land, unless they obtain the consent of the National Support Centre for Agriculture, because they cease to be a close relative of the seller after the marriage ends. This solution would also have to be applied if it was the spouse who, not being an individual farmer from the point of view of the Act, contributed agricultural property to the joint property. In addition, the Act affected the course of the enforced debt collection-after the law was amended in 2016, agricultural real estate can be purchased at a bailiff auction only by a person who meets the statutory criteria of an individual farmer.

Practical issues also arose in relation to the valuation of agricultural land (lack of sufficient market transactions), which made it difficult to establish mortgages. According to the Polish law, the sum of a mortgage on agricultural real estate cannot exceed the market value of this real estate, established on the day of establishing the mortgage lien. The real estate value is established by a property appraiser in an appraisal report. The entry into force of the Act led to a temporary blocking, lasting until July 2016, of the establishment of mortgage lines on agricultural real estate.

\section{Discussion}

The land is a special good, and agricultural producers are a special profession [54]. State intervention on the agricultural land market is therefore necessary because the market mechanism, shifting this resource to the most competitive areas (e.g., construction, road infrastructure) may cause irrational, irretrievable loss to non-agricultural use, which in turn could threaten the food and energy security of the country.

Many countries around the world are trying to prevent the misuse of agricultural land by restricting trade in it. State interventionism in agricultural real estate trade as a means of controlling the structure of farms is nothing new in Western European countries (Table 1) and it dates back to the 1970s [52,55]. Since then, European countries have been supplementing the laws on the agricultural real estate market or making them more rigorous. Various instruments are being used to maintain or improve farm structures, as letting the trade be regulated by the market alone would lead to the over-concentration and/or fragmentation of farms and to the use of agricultural land for non-agricultural purposes. This would threaten both the stability of the agricultural sector and the food security of the state.

In EU Member States, it is common to use several instruments simultaneously and to divide them into models with defined sizes, as well as solutions requiring an effort on the part of administrative authorities, such as functional checks of the potential effects of transactions. Although the rules introduced in Poland are similar to those used in the EU Member States, they have caused great dissatisfaction among the owners of agricultural real estate, who have been accustomed to the possibility of obtaining significant income from the sale of land. It should be stressed that both the purchase by a public entity (APA), when agricultural land is sold to a non-agricultural entity, and the maximum size of a family farm is based on the practice in other EU Member States, but they were introduced without preparing agricultural real estate market participants in Poland. The possibility of state intervention in the agricultural real estate market existing until May 2016 was not used in reality. 
Table 1. Methods of state intervention in the trade in agricultural real estate in EU states.

\section{Instruments Applied to \\ Restrict Trade in \\ Agricultural Real Estate}

\section{Characteristics}

a. Roman model (France, Italy) refers directly to a specified standard defining the minimum size of a farm, where neither as a result of marketing nor as a result of inheritance can the farm be reduced below this limit. A modified solution has now been adopted in France, which allows the definition of a separate standard, based on the conversion of a minimum farm size allowing at least two full-time workers to support themselves. b. Germanic model (Germany, Portugal, Austria, Denmark, Sweden, Ireland, Finland, the Netherlands) rejects strictly specified area limits in favour of a functional definition of a minimum farm area as sufficient for the production of goods and the maintenance of an average family. The impact of a potential division is assessed by administration and courts. c. mixed model (Spain): transition from a solution similar to the Romanesque model to a functional minimum size, where the farm has to provide an income to support a family.

Application of these rules is often excluded with respect to a transfer of farm ownership within the family. The usual solutions are specific area size standards, their potential excess means that the administrative authority has to be asked for approval. Such provisions exist in France, Denmark, and the Netherlands. The option referring to the number of farms is also used. Another basic way of restricting excessive concentration of farms is to assess whether the enlargement of a farm is rational; this solution is in force in Germany and Austria.

These provisions may vary in detail, ranging from the requirement to have theoretical agricultural qualifications and/or to live and manage a farm in person (Germany, Denmark); practical farm management experience (France, Austria, The Netherlands, Denmark, Spain); stricter regulations applying to legal persons (Sweden, Denmark, The Netherlands); to the requirement for appropriate qualifications also applying to the lease of agricultural land, in particular, of a long-term nature (Italy, Ireland).

The entities entitled to the right of pre-emption are neighbors. Such a regulation is in force in France, Italy, and Spain. The members of the seller's family are entitled in Italy and Spain. In Germany, Italy and France, these are specialized entities, both public and private. Often, if the latter is the case in a given country, the purchaser is obliged to sell the agricultural property within the next 5 years. pre-emption of agricultural real estate

This solution is in force in Spain as the granting of special status and protection to family farms.

These sanctions can vary in severity, ranging from the most severe, such as the statutory purchase of land (applicable in Sweden and Finland) and invalidity of a legal act (Austria, Spain, Sweden). Another way of disciplining those who break the restrictions is the inability to make an entry in the register of rights to real estate, which results in the transfer being ineffective (Germany, Denmark, The Netherlands, Finland). In Germany, Denmark, France, The Netherlands, and Spain, the right to control the contents of contracts applies. Financial penalties are also common in these countries.

Source: [56,57].

\section{Conclusions}

The article attempts to describe selected elements of the situation on the agricultural land market and the assumptions of the policy in this respect in Poland. The main objective was to investigate the real effects of the introduction of a radical act of 2016 aimed at combating the misuse of agricultural land. 
The results of the conducted research indicate that the impact of the new legislation is both positive and negative. The positive aspects include a reduction in the number of speculative transactions and the concentration of housing development in agricultural areas, which favours the sustainable use of agricultural land. However, the positive effects are offset by negative ones, such as attempts to circumvent the existing regulations (e.g., in the scope of regulating the boundaries of land or selling the land to persons who do not meet the requirements of the regulations).

Activities conducted on the agricultural land market cannot be undertaken in a hurry, e.g., due to the necessity of accession to the European Union (Act of 11 April 2003 on shaping the agricultural system), or due to the ending of the transitional period for the acquisition of agricultural real estate by foreigners (Act of 14 April 2016 on suspending the sale of agricultural property of the State Treasury). As the results show, underdeveloped legal acts do not contribute to the improvement of the functioning of the agricultural land market in Poland, on the contrary, they inhibit welcome changes. The effects of new regulations were felt first of all by the owners of agricultural real estate. As the research shows, the number of transactions concluded on the agricultural real estate market in typically agricultural districts significantly decreased. The above considerations confirm the need for further changes to ease the new restrictions. The response to the above premises is the introduction of new provisions in the Act of April 2019, to alleviate the restrictions on agricultural real estate trade. Firstly, the size of agricultural real estate which can be acquired by a person who is not an individual farmer was increased from 0.3 ha to 1 ha. Including 1 ha plots of land in the free trade may enable agricultural farms to obtain funds necessary for financing their activities or debt restructuring, and at the same time it will reduce the practice of dividing and decreasing the size of plots of land. Another change involves exclusion of the requirement that having individual farmer status is necessary for purchasing agricultural real estate in the course of enforcement and bankruptcy proceedings, which should prevent a paralysis of such proceedings, resulting from a radical restriction of the group of persons entitled to participate in agricultural real estate auctions. The amendment also excluded from the range of the Act the acquisition of property as a result of the abolition of co-ownership, division of joint property after the termination of marriage and division of inheritance, as well as a result of division, transformation or merger of commercial companies. These changes meet the calls for making trade regulations more flexible in areas where a relatively small agricultural real estate does not pose a threat to the agricultural use of agricultural real estate or the structure of individual farms in Poland. The Act specifies the procedure to be followed and the prerequisites for the acquisition of agricultural real estate as a result of the consent granted by the General Manager of the Agricultural Property Agency by specifying the requirements for an application for consent. In order to reduce the fiction of displaying announcements, a procedure has been introduced to publish a free-of-charge announcement on the sale of agricultural real estate on an IT platform run by the NSCA.

Author Contributions: Conceptualization, methodology, analysis, investigation, writing preparation and visualisation: A.Ź.-R. and J.Z.-S. (50\%/50\%).

Funding: This research was funded by Krajowy Ośrodek Wsparcia Rolnictwa (National Support Centre for Agriculture), grant number 03/SFKiW/2017 and University of Warmia and Mazury in Poland. The APC was funded by Krajowy Ośrodek Wsparcia Rolnictwa (National Support Centre for Agriculture), grant number 02/WFKIW/2019.

Acknowledgments: The authors acknowledge National Support Centre for Agriculture for funding the research and all the offices workers, who support our study by giving us detailed information on the practical aspect of the new regulations.

Conflicts of Interest: The authors declare no conflict of interest. The funders had no role in the design of the study; in the collection, analyses, or interpretation of data; in the writing of the manuscript, or in the decision to publish the results. 


\section{References}

1. Food and Agriculture Organization of the United Nations. Available online: http://www.fao.org/faostat/en/ \#home (accessed on 11 October 2019).

2. Jeżyńska, B.; Pastuszko, R. Obrót nieruchomościami rolnymi a prawo Unii Europejskiej (Agricultural property trade and European Union law). Probl. Rol. Światowego 2018, 18, 156-164. (In Polish)

3. Busko, M.; Szafranska, B. Analysis of changes in land use patterns pursuant to the conversion of agricultural land to non-agricultural use in the context of the sustainable development of the Malopolska Region. Sustainability 2018, 10, 136. [CrossRef]

4. Fitton, N.; Alexander, P.; Arnell, N.; Bajzelj, B.; Calvin, K.; Doelman, J.; Gerber, J.S.; Havlik, P.; Hasegawa, T.; Herrero, M.; et al. The vulnerabilities of agricultural land and food production to future water scarcity. Glob. Environ. Chang. 2019, 58, 101944. [CrossRef]

5. Huang, Z.; Du, X.; Castillo, C.S.Z. How does urbanization affect farmland protection? Evidence from China. Resour. Conserv. Recycl. 2019, 145, 139-147. [CrossRef]

6. Źróbek-Różańska, A.; Zadworny, D. Can urban sprawl lead to urban people governing rural areas? Evidence from the Dywity Commune, Poland. Cities 2016, 59, 57-65. [CrossRef]

7. Zhang, L.; Wu, B.; Zhu, L.; Wang, P. Patterns and driving forces of cropland changes in the three Gorges area, China. Reg. Environ. Chang. 2012, 12, 765-776.

8. Rimal, B.; Zhang, L.; Fu, D.; Kunwar, R.; Zhai, Y. Monitoring urban growth and the Nepal earthquake 2015 for sustainability of Kathmandu valley, Nepal. Land 2017, 6, 42. [CrossRef]

9. Alexander, P.; Rabin, S.; Anthoni, P.; Henry, R.; Pugh, T.A.M.; Rounsevell, M.D.A.; Arneth, A. Adaptation of global land use and management intensity to changes in climate and atmospheric carbon dioxide. Glob. Chang. Biol. 2018, 24, 2791-2809. [CrossRef]

10. Bowles, N.; Alexander, S.; Hadjikakou, M. The livestock sector and planetary boundaries: a 'limits to growth' perspective with dietary implications. Ecol. Econ. 2019, 160, 128-136. [CrossRef]

11. Busch, J.; Ferretti-Gallon, K. What drives deforestation and what stops it? A meta-analysis. Rev. Environ. Econ. Policy 2017, 11, 3-23. [CrossRef]

12. Hosonuma, N.; Herold, M.; De Sy, V.; DeFries, R.S.; Brockhaus, M.; Verchot, L.; Angelsen, A.; Romijn, E. An assessment of deforestation and forest degradation drivers in developing countries. Environ. Res. Lett. 2012, 7, 4009. [CrossRef]

13. Marselis, S.M.; Feng, K.; Liu, Y.; Teodoro, J.D.; Hubacek, K. Agricultural land displacement and undernourishment. J. Clean. Prod. 2017, 161, 619-628. [CrossRef]

14. Nunez, D.G. Peasants' right to land: Addressing the existing implementation and normative gaps in International Human Rights Law. Hum. Rights Law Rev. 2014, 14, 589-609. [CrossRef]

15. Cotula, L. Addressing the Human Rights Impacts of Land Grabbing; EU Publications: Brussels, Belgium, 2015. [CrossRef]

16. Zawojska, A. Zjawisko zagrabiania ziemi w kontekście praw własności (The phenomenon of landgrabbing in the context of property rights). Pr. Nauk. Uniw. Ekon. We Wroctawiu 2014, 361, 269-280. (In Polish)

17. Zeb, A.; Hamann, A.; Armstrong, G.W.; Acuna-Castellanos, D. Identifying local actors of deforestation and forest degradation in the Kalasha valleys of Pakistan. For. Policy Econ. 2019, 104, 56-64. [CrossRef]

18. Janus, J.; Bozek, P. Land abandonment in Poland after the collapse of socialism: Over a quarter of a century of increasing tree cover on agricultural land. Ecol. Eng. 2019, 138, 106-117. [CrossRef]

19. Brown, C.; Alexander, P.; Arneth, A.; Holman, I.; Rounsevell, M. Achievement of Paris climate goals unlikely due to time lags in the land system. Nat. Clim. Chang. 2019, 9, 203-208. [CrossRef]

20. Vermeulen, S.J.; Dinesh, D.; Howden, S.M.; Cramer, L.; Thornton, P.K. Transformation in practice: A review of empirical cases of transformational adaptation in agriculture under climate change. Front. Sustain. Food Syst. 2018, 2, 65. [CrossRef]

21. Brundtland, G.; Khalid, M.; Agnelli, S.; Al-Athel, S.; Chidzero, B.; Fadika, L.; Hauff, V.; Lang, I.; Shijun, M. Report of the World Commission on Environment and Development: Our Common Future ('Brundtland Report'); United Nations: New York, NY, USA, 1987.

22. Meadowcroft, J. Who is in charge here? Governance for sustainable development in a complex world. J. Environ. Policy Plan. 2007, 9, 299-314. [CrossRef] 
23. Koguashvili, P.; Ramishvili, B. Specific of agricultural land's price formation. Ann. Agrar. Sci. 2018, 16, 324-326. [CrossRef]

24. Zákon zo 16. Maja 2014 o nadobúdaní vlastníctva pol'nohospodárskeho pozemku a o zmene a doplneníniektorýchzákonov, 140/2014 (Act of 16 May 2014 on Acquisition of Ownership of Agricultural Land and on Amendments to Certain Acts, 140/2014. (In Slovak). Available online: https://www.epi.sk/zz/2014-140 (accessed on 13 November 2019).

25. évi CXXII. törvény a mezoó- éserdőgazdaságiföldek forgalmáról.2013. évi CXXII. törvény a mezőéserdőgazdaságiföldekforgalmáról (CXXII of 2013 Act on the turnover of agricultural and forestry land. year CXXII. Law on the sale of agricultural and forestry land. (In Hungarian). 2013. Available online: https://net.jogtar.hu/jogszabaly?docid=a1300122.tv (accessed on 13 November 2019).

26. Ustawa z dnia 14 kwietnia 2016 r. o wstrzymaniu sprzedaży nieruchomości Zasobu Własności Rolnej Skarbu Państwa oraz o zmianie niektórych ustaw (Act of 14 April 2016 on suspension of sale of the property of the Agricultural Property Stock of the Treasury and on amendment of certain acts. (In Polish). Available online: http://prawo.sejm.gov.pl/isap.nsf/DocDetails.xsp?id=WDU20160000585 (accessed on 13 November 2019).

27. Gada 16. janvāra likums “Grozījumi likumā „Par zemes privatizāciju lauku apvidos”. Publicētsoficiālajāizdevumā "LatvijasVēstnesis", 24.01.2014, Nr. 17, 5076; (Law of 16 January 2014 “Amendments to the Law on Land Privatization in Rural Areas"); Official Gazette LatvijasVēstnesis: Riga, Latvia, 2014; 24.01.2014, no. 17; p. 5076. (In Latvian)

28. Žemėsūkiopaskirtiesžemèsı̨sigijimolaikinojoı̨statymo 5 straipsniopakeitimo, Valstybèsžinios, 2013-07-16, Nr. 76-3836(Amendment to Article 5 of the Provisional Law on the Acquisition of Agricultural Land, Official Gazette, 16.07.2013, no. 76-3836. (In Lithuanian). Available online: https://www.lrkt.lt/en/court-acts/ search/170/ta1350/content (accessed on 13 November 2019).

29. Закон засобственосттаи ползванетона земе делскитеземи, загл. изм.-ДВ, БР. 14 OT2015 Г. (Law on Ownership and Use of Agricultural Land, title ed. - DV, BR. 14 OT 2015. (In Bulgarian). Available online: http://extwprlegs1.fao.org/docs/pdf/bul164528.pdf (accessed on 13 November 2019).

30. Legenr. 17 din 7 martie 2014 Privind unele Măsuri de Reglementare a Vânzării-Cumpărării Terenurilor Agricole Situate înextravilan şi de Modificare a Legiinr. 268/2001 Privind Privatizarea Societăţilor Comerciale ce DeţIn în Administrare Terenuri Proprietate Publică şi Privată a Statului cu Destinaţie Agricolă şi înfiinţarea Agenţiei Domeniilor Statului, Monitorul Oficialnr. 178 din 12 Martie 2014 (Law no. 17 of March 7, 2014 on Some Measures to Regulate the Sale-Purchase of Agricultural Lands Located in the Outskirts and Amending the Law No. 268/2001 Regarding the Privatization of the Commercial Companies that Hold in Public Lands Public and Private Property of the State With Agricultural Destination and the Establishment of the State Domains Agency, the Official Monitor no. 178 of March 12, 2014. (In Romanian). Available online: http://legislatie.just.ro/Public/DetaliiDocument/158620 (accessed on 13 November 2019).

31. Treaty on the Functioning of the European Union. Official Journal of the European Union. Available online: https://eur-lex.europa.eu/legal-content/EN/TXT/?uri=celex\%3A12012E\%2FTXT (accessed on 13 November 2019).

32. Mandal, S.; Misra, G.V.; Naqvi, S.M.A.; Kumar, N. Situational analysis of agricultural land leasing in Uttar Pradesh. Land Use Policy 2019, 88, 104106. [CrossRef]

33. Dekret Polskiego Komitetu Wyzwolenia Narodowego z dnia 6 września 1944 r. (Decree of the Polish Committee of National Liberation of September 6, 1944. (In Polish). Available online: http://prawo.sejm.gov. pl/isap.nsf/DocDetails.xsp?id=WDU19440040017 (accessed on 13 November 2019).

34. Rychlik, T. Państwowe gospodarstwa rolne w rolnictwie polskim (State-owned farms in Polish agriculture. In Poradnik dla Kadry Kierowniczej PGR (A Guidebook for PGR Executives); Państwowe Wydawnictwo Rolnicze i Leśne: Warszawa, Poland, 1972; pp. 13-26. (In Polish)

35. Wilamowski, B.; Burzyński, K. Przekształcanie obszarów wiejskich na przykładzie województwa olsztyńskiego (Transformation of rural areas on the example of the Olsztyn Voivodship). In Proceedings of the Konferencja TUP, Olsztyn, Poland, 16-17 October 1978. (In Polish).

36. Zapotoczna, M.; Łaguna, D. Wpływ Zmian Zachodzacych w Przestrzeni Wiejskiej na Poziom Życia Mieszkańców w Wybranych Gminach Województwa-Część I (The Influence of Changes in Rural Areas on the Quality of Life of the Inhabitants in Selected Communes in Warmia and Mazury Voivodeship-Part I); Infrastruktura i Ekologia Terenów Wiejskich: Krakow, Poland, 2018; Volume 1, pp. 163-181. 
37. Marks-Bielska, R.; Kisiel, R.; Lizińska, W. Uwarunkowania polityki polskiego rządu odnośnie rynku ziemi rolniczej w kontekście zakończenia okresu przejściowego nabywania nieruchomości rolnych przez cudzoziemców (Determinants of the Polish government's policy regarding the agricultural land market in the context of the end of the transitional period for the acquisition of agricultural property by foreigners. Probl. Drob. Gospod. Rol. 2017, 3, 15-27. (In Polish)

38. Karaszewski, W.; Jaworek, M.; Siemińska, E. Bezpośrednie inwestycje zagraniczne i ich oddziaływanie na gospodarke regionu przyjmujacego (Foreign direct investment and its impact on the economy of the host region). In Bezpośrednie Inwestycje Zagraniczne w Wybranych Województwach Polski-Analiza Porównawcza (Foreign Direct Investment in Selected Polish Voivodships-Comparative Analysis); Karaszewski, W., Ed.; Wydawnictwo Uniwersytetu Mikołaja Kopernika: Toruń, Poland, 2005; pp. 23-65. (In Polish)

39. Ustawa z dnia 23 kwietnia 1964 r-Kodeks cywilny (Act of April 23, 1964-Civil Code. (In Polish). Available online: http://prawo.sejm.gov.pl/isap.nsf/DocDetails.xsp?id=wdu19640160093 (accessed on 13 November 2019).

40. Ustawa z dnia 6 lipca 1982 r. o księgach wieczystych i hipotece (Act of July 6, 1982 on land and mortgage registers. (In Polish). Available online: http://prawo.sejm.gov.pl/isap.nsf/DocDetails.xsp?id= WDU19820190147 (accessed on 13 November 2019).

41. Ustawa z dnia 17 maja 1989 r.-Prawo geodezyjne i kartograficzne (Act of 17 May 1989—Geodetic and cartographic law. (In Polish). Available online: http://prawo.sejm.gov.pl/isap.nsf/DocDetails.xsp?id= WDU19890300163 (accessed on 13 November 2019).

42. Ustawa z dnia 19 października 1991 r. o gospodarowaniu nieruchomościami rolnymi Skarbu Państwa (The Act of 19 October 1991 on the management of agricultural property of the Treasury. (In Polish). Available online: http://prawo.sejm.gov.pl/isap.nsf/download.xsp/WDU20120001187/T/D20121187L.pdf (accessed on 13 November 2019).

43. Ustawa z dnia 11 kwietnia 2003 r. o kształtowaniu ustroju rolnego (Act of 11 April 2003 on shaping the agricultural system. (In Polish). Available online: http://prawo.sejm.gov.pl/isap.nsf/DocDetails.xsp?id= WDU20030640592 (accessed on 13 November 2019).

44. Ustawa z dnia 8 lipca 2005 r. o realizacji prawa do rekompensaty z tytułu pozostawienia nieruchomości poza obecnymi granicami Rzeczypospolitej Polskiej (Act of 8 July 2005 on exercising the right to compensation for leaving real estate outside the current borders of the Republic of Poland. (In Polish). Available online: http://prawo.sejm.gov.pl/isap.nsf/DocDetails.xsp?id=WDU20051691418 (accessed on 13 November 2019).

45. Ustawa z dnia 26 kwietnia 2019 r. o zmianie ustawy o kształtowaniu ustroju rolnego oraz niektórych innych ustaw (Act of 26 April 2019 amending the act on shaping the agricultural system and certain other acts. (In Polish). Available online: http://prawo.sejm.gov.pl/isap.nsf/DocDetails.xsp?id=WDU20190001080 (accessed on 13 November 2019).

46. Kucharska-Stasiak, E. Ekonomiczny Wymiar Nieruchomości (The economic Dimension of the Property); PWN: Warszawa, Poland, 2016. (In Polish)

47. Kryszk, H.; Kurowska, K. Legal and market-related conditions underlying management of state treasury agricultural real estate in Polan. In Proceedings of the 16th International Scientific Conference Engineering for Rural Development, Jelgava, Latvia, 24-26 May 2017.

48. Czyżewski, A.; Kułyk, P. Płatności bezpośrednie a interesy polskiego rolnictwa (Direct payments and the interests of Polish agriculture. Problemy Rolnictwa Światowego. Zesz. Nauk. Szkoły Głównej Gospod. Wiej. W Warszawie 2008, 4, 19. (In Polish)

49. Kisiel, R.; Babuchowska, K.; Marks-Bielska, R. Wykorzystanie Dopłat Bezpośrednich Przez Rolników z Województwa Warmińsko-Mazurskiego (The Use of Direct Payments by Farmers from the Warmian-Masurian Voivodeship); Wyd. UWM Olsztyn: Olsztyn, Poland, 2008. (In Polish)

50. Wilkin, J. Ekonomia polityczna reform Wspólnej Polityki Rolnej (Political economy of reforms of the Common Agricultural Policy. Gospodarka Narodowa 2009, 1-2, 209-210. (In Polish)

51. Ostre Cięcia w Obrocie Ziemia Maja Odejść do Przeszłości (Sharp Cuts in Earth Turnover are a Thing of the Past). Available online: www.nik.gov.pl (accessed on 13 September 2019). (In Polish)

52. Król, M. Przegląd Wspótczesnych Instrumentów Wspierajacych Zmiany Struktury Obszarowej Gospodarstw Rolnych $i$ Wymiane Pokoleniowa $w$ Rolnictwie w Wybranych Krajach Europejskich (Review of Contemporary Instruments Supporting Changes in the Area Structure of Farms and Generational Exchange in Agriculture in Selected European Countries); Fundacja Programów Pomocy dla Rolnictwa: Warszawa, Poland, 2013. (In Polish) 
53. Kowalczyk, C.; Nowak, M.; Źróbek, S. The concept of studying the impact of legal changes on the agricultural real estate market. Land Use Policy 2019, 86, 229-237. [CrossRef]

54. Zielińska-Szczepkowska, J.; Kisiel, R. Zrzeszanie się Producentów Rolnych Jako Przykład Wspótdziałania w Sektorze Rolnictwa-Doświadczenia Wybranych Krajów Członkowskich Unii Europejskiej (Association of Agricultural Producers as an Exampleof Cooperation in the Agricultural Sector-The Experienceof Selected EU Countries); Zeszyty Naukowe Szkoły Głównej Gospodarstwa Wiejskiego w Warszawie: Warszawa, Poland, 2016; Volume 16, pp. 372-386.

55. Stankiewicz, D. Ograniczenia w Obrocie Gruntami Rolnymi w Wybranych Krajach Unii Europejskiej w Aspekcie Prac nad Stosownymi Zmianami w Ustawodawstwie Polskim (Restrictions on Trade in Agricultural Land in Selected European Union Countries in the Aspect of Work on Relevant Changes in Polish Legislation); Biuro Studiów i Ekspertyz, Wydział Analiz Ekonomicznych i Społecznych: Warszawa, Poland, 2002. (In Polish)

56. Ciaian, P.; Kancs, D.A.; Swinnen, J.; van Herck, K.; Vranken, L. Sales Market Regulations for Agricultural Land in EU Member States and Candidate Countries. Factor Markets; Working Paper No. 14; Centre for European Policy Studies: Brussel, Belgium, 2012.

57. Pijanowska, J.; Brożyna, M. Wybraneaspektyprawneobrotuzasobamiziemirolniczej w Polscepozmianieprawa w 2016 roku (Selected legal aspects of trade in agricultural land resources in Poland after the change of law in 2016. Zesz. Nauk. Szkoły Głównej Gospod. Wiej. Ekon. I Organ. Gospod. Żywnościowej 2018, 123, 43-53. (In Polish)

(C) 2019 by the authors. Licensee MDPI, Basel, Switzerland. This article is an open access article distributed under the terms and conditions of the Creative Commons Attribution (CC BY) license (http://creativecommons.org/licenses/by/4.0/). 